\title{
Críticas em fac-símile publicadas no jornal Estado de S. Paulo
}

\author{
Mariângela Alves de Lima
}

Mariângela Alves de Lima

Pesquisadora e crítica de teatro.

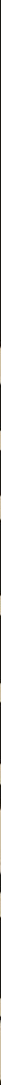




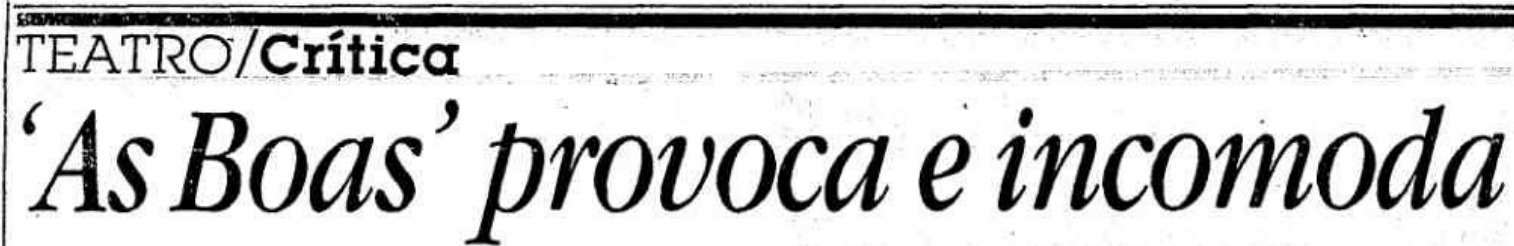

\section{Mariangela Alves de Lima Especial para o Estado}

A to vola ao palco, depois de anos de exílio intermitente, José Celso Martinez Correa impulsiona para o primeiro plano da cena a marca de origem da sua geração: o teatro social. Na liderança artística do Oficina José Celso oferecia ans espectadores uma crítica implacável do seu desempenho coletivo. Mas, durante os anos em que ficou alusente do palco, o entomo teatral mudou bastante. Tornaram-se mais visiveis, na superficie da vida teatral, as questōes da linguagem e das leis internas que regem a feitura do espetáculo. Há razões complexas para isso, e una delas é a suposiçio de que teriamos chegado ao fím da história ou, na versão mais apocalíptica, ao fim dos tempos. O espetáculo, vivend̦o no efêmero e apostando na fruicĩo, resumiria toda a possibilidade do teatro. Preso a essa trama de conceitos resta ao artista a linguagem, sua obsessão primordial.

É um teatro que não pode ser belo porque expulsa deliberadamente as idealizações. Não comporta a piedade porque considera o que vivemos como produção huma. na. E isso que As Boas de José Celso pöe em cena, com extraordinária fidelidade à formação do encenador.

José Celso escolheu a parceria de Jean Genet, um autor cujo tema central é o desempenho do papel na engrena. gem social. Tanto para o encenador quanto para o dramaturgo o desempenho social é um modelo de onde deriva a produção simbólica. Parn ambos o teatro é, antes de tudo, o lugar onde se engrandecem os conflitos e as determinaçōes do social. Por isso a cerimônia executada pelas criadas de Genet não é uma metáfora (o que permitiria ao espectador operaçōes analógicas) mas um espelhamento.

As Boas é um espetáculo concebido para repropor, sem ambigüidade, a trama das relações entre o senhor eo escravo. Regido pelo mecanismo da dominação, o espetáculo não permite ilusões sobre os papéis desepenhados no palco ou fora de cena, pelos próprios espectadores. À maneira de Brecht, José Celso mostra que o público não está lá para ser iludido ou acaricia. do. A única secluçào que o espetâ. culo comporta é a presença de Madame. Ansiada e temida, a aparição de Madiame, interpretada por Raul Cortez, é uma aterrorizante efigie do poder. Como aś criadas, o público está à mercê de Madame.

Bastaria esse terror sem som. bras, iluminado pela consciência crítica, tomando irrelevantes as categorias do gosto ou do bem-feito, para justificar a força do espetáculo de José Celso. Entretanto, há ainda outras coisas querendo entrar em cena, elementos indistintos que perturbam a funçâo demonstrativa do espatáculo. Quando isola um espectador na platéia, escothendo-o como alio de sua fala, o ator José Celso rompe o caráter

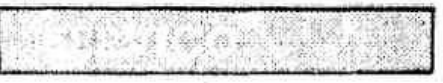

As Boas - De.fean Genet. Centro Cultural Sấo Patilo - Sala

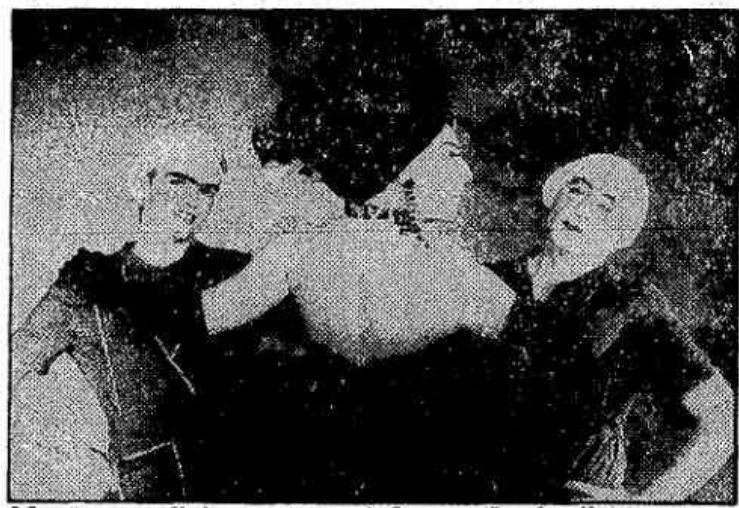

Montagem fiel ao autor e à formaçäo do diretor

coletivo da cerimônia que concebeu como encenador. Faz, ele mesmo, a identificação das "criadas" ou das "madames", tomando-se, nesse momento, escravo da subjetividade que quer descartar do teatro. Por um instante o espetáculo abre uma brecha para o deboche.

A contradição maior se localiza na última cena, em que aparece o desejo, ainda que invertido, de um happy end. Incluindo Madame em uma hecatombe final José Celso realiza o rito do teatro, e não o da sociedade, separando o que, para ele mesino, seria indissolúvel. Genet ganha de Zé Celso porque mostra que se pode combater o senhor em efigie, mas não vencê-lo dessa forma. Também o uníssono que encerra o espetáculo, que deveria harmonizar artistas e público, contraria tudo o que o precede. É evidente que José Celso quer agregar alguma coisa à lucidez crítica que o caracteriza. Mas isso está ainda à margem do seu teatro. Fazia imensa falta a presença de Zé Celso no palco. O espetáculo que faz nos toma incapazes de olhar sem ver. Suas contradições nos mandam para fora do teatro discordantes, mobilizados. E o que quer pôr em cena, mas ainda não conseguiu, é, talvez, o que precisamos ver e ainda não divisamos.

\section{ESCOLHA}

\section{O PONTO DA GARNE: HADDOCK LOBO, ALPHAVILLE
OU MORUMBI.}

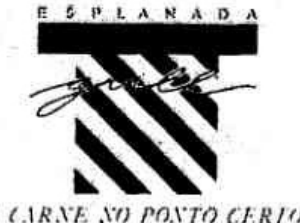




\section{Ela (1997)}

\section{Zé Celso seduz pela força da representação}

Poucos encenadores são capazes de produzir ilusões tão eloqüentes quanto o diretor

MARIANGELA ALVES DE LIMA Especial paru o Estado

A representação da representaçao tem sido, desde vilegiados pelo Teatro Oficina. As representaçóes criadas pelo autoritarismo mereceram tant atençao quanto seu inverso. aquelas sensaçoes produzida como rito benigno de aproximaçào com o outro. Sem ignorar que está diante de uma potência, o Oncina traz a discussão para o plano da ética.

Oe pasoes vivido por esse trupe que aspira a "comunhà dos corpos". Poucos encenadores sào capazes de produzir ilusóes tảo eloqüentes quanto as que proliferam sob a batuta de José Celso Martinez Corrêa. E nenhum outro entre nos se aproxima tanto do ponto em que a representaça é substituida por uma manifestação
vital de público e dos atores. E é dessa dialética da comunicaçáe que trata agora o texto de Jean

Em Ela, em cartaz no Teatro Oficina Uzyna Uzona, um fotoreproduzir a figura de up Frente sem fundo, aparência. em essência e objeto a ser fototrafado deseja e teme a captura da máquina fotogrática. "Est potência, esta realidade, vem da minha imagem; eu vivo esta contradiçáo sem síntese",

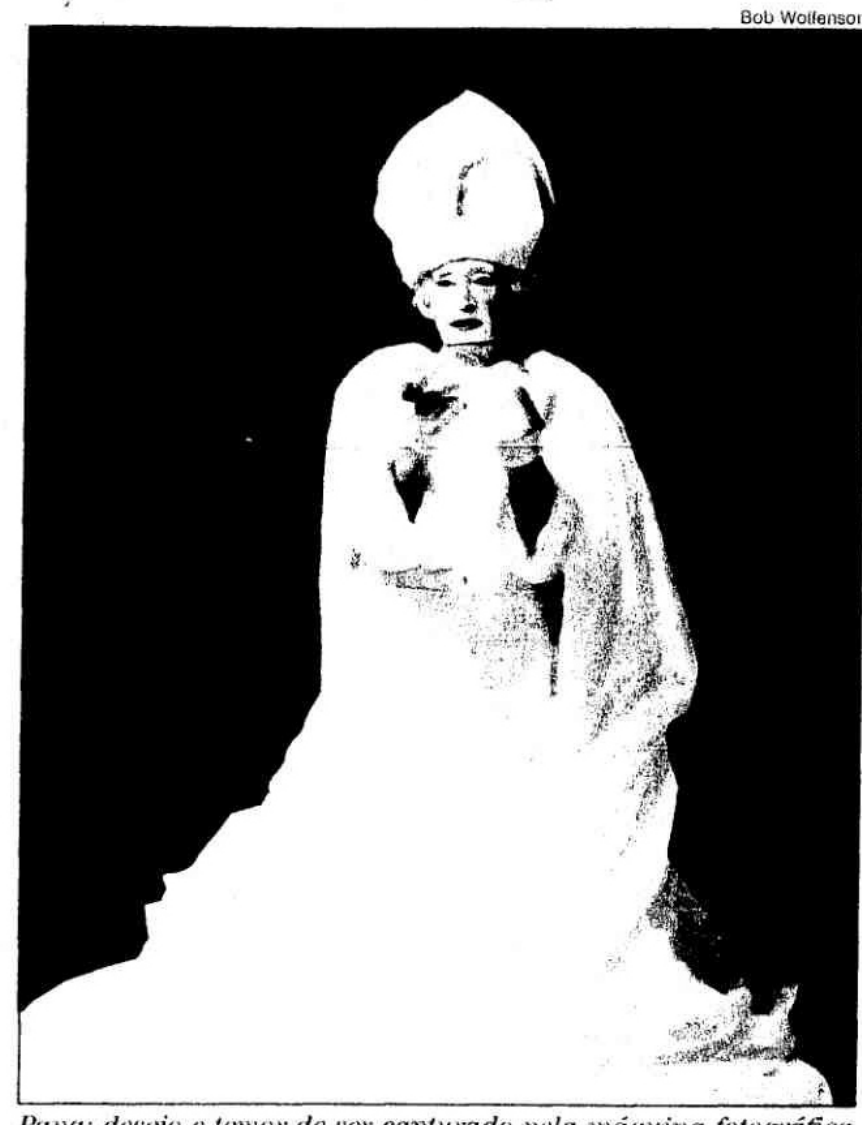

Papa: desejo e temor de ser capturado pela máquina fotográfica dirá o papa. O poder pontificial sugere Genet - repousa sovar e estimular a consumo de uma imagem.

Nac fosse Genet um grande escritor e José (celso um encenador de igual porte estariamos diante de um truísmo já exaurimunicacão de aos meios de co10, as figuras da peca são, além de belas alegorias, a expressã de uma competente demonstra ao argumentativa Nessa pec. Genet filia-se a uma tradiçáo d.

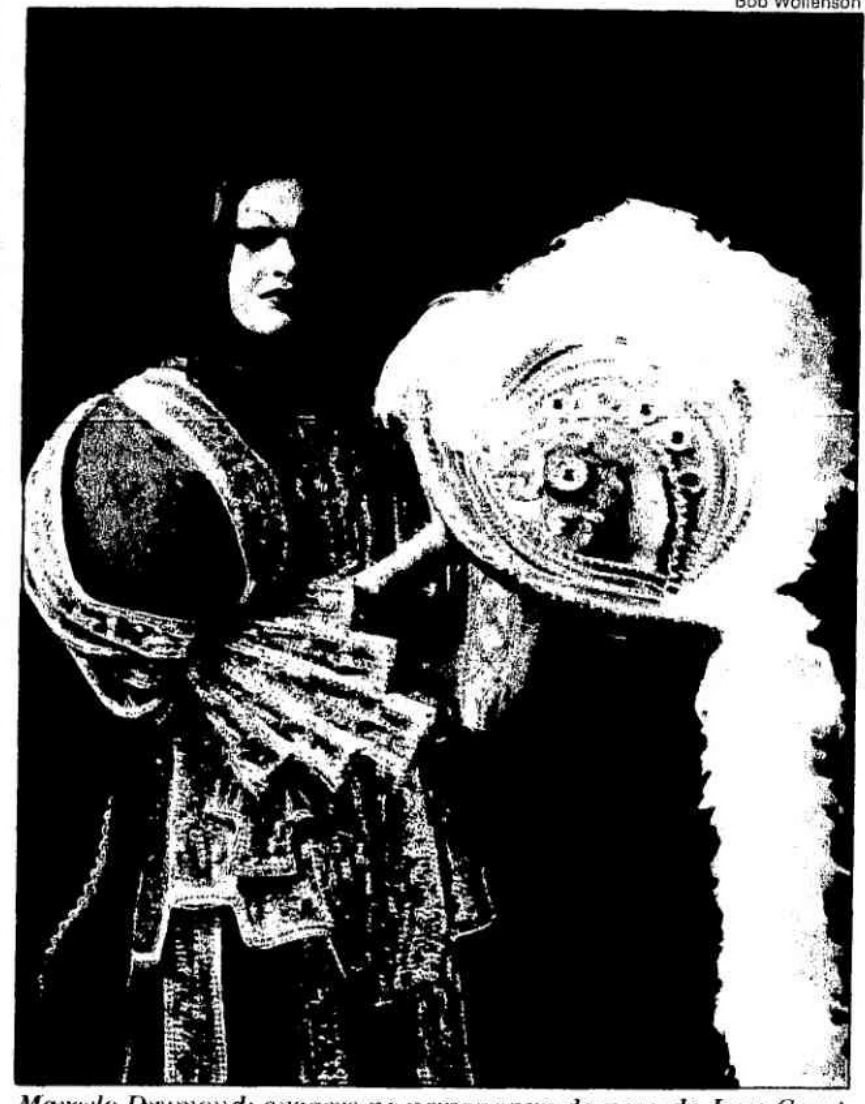

Marcelo Drumond: exagero no personagem da peca de Jean Gemet teatro francês de não poupar pobres como a realidade. aos espectadores o desafio de No espetáculo, o Oficina reali coma boa discussão intelectual. $2 a$ com o mais absoluto rigo frestas uma irrisao. pequenas da comagem grande imiscuir se na ficcáo Indican mecanismo interno de produ-

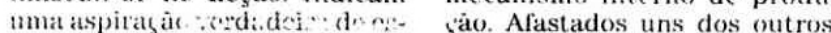

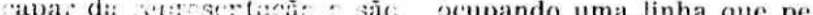

orre a extensão do teatro, os personagens aparecem com abstraçoes, longinquos e evocatives. Tem, porem, de modo visivel, algum ponto inacabado ou algum exagero indicando uma aparência produzida.

Os diálogos claros - uma ve que discutem a potência figuracheram ao espam a distancia clareza e a inteligência nom rias para que se posia compreender os termos do paradoxo. Somos $\mathrm{cm}$ igual medida se duzidos e esclarecidos pela força da representação e pelos conceitos que a destroem.

Clamor - A essa crítica de caráter fenomenológico, o Oficin acrescenta o seu grào de sal. Seu espetáculo termina com um vigoroso brado clamando pela consciencia histórica e pela nosde a m marcha fora de tea coisa qual é preciso estar atento. Ainda assim a tarefa do teatro é ropresentar e, por essa razio, Antônio Conselheiro que entra $\mathrm{m}$ cena simbolizando csses mihoies de vozes e rostos que nun'a integrarão as imagens criadas pelo poder.

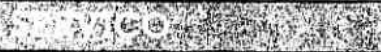
Ba. Terto de Jean Genet Traduscio de Zé Celso e Catherine Hirsch. Direscro de Zé Celso. Com

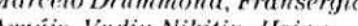
aranjo, Vadin Nititin. Hojee ais 19 horas 25 an 00 , domingo. payum meiti). Teatro Oficing Uzyna lyona. Run Jucrumi 606.2818 


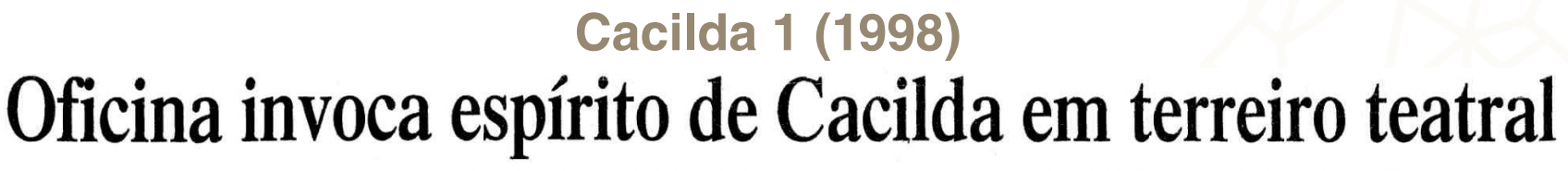

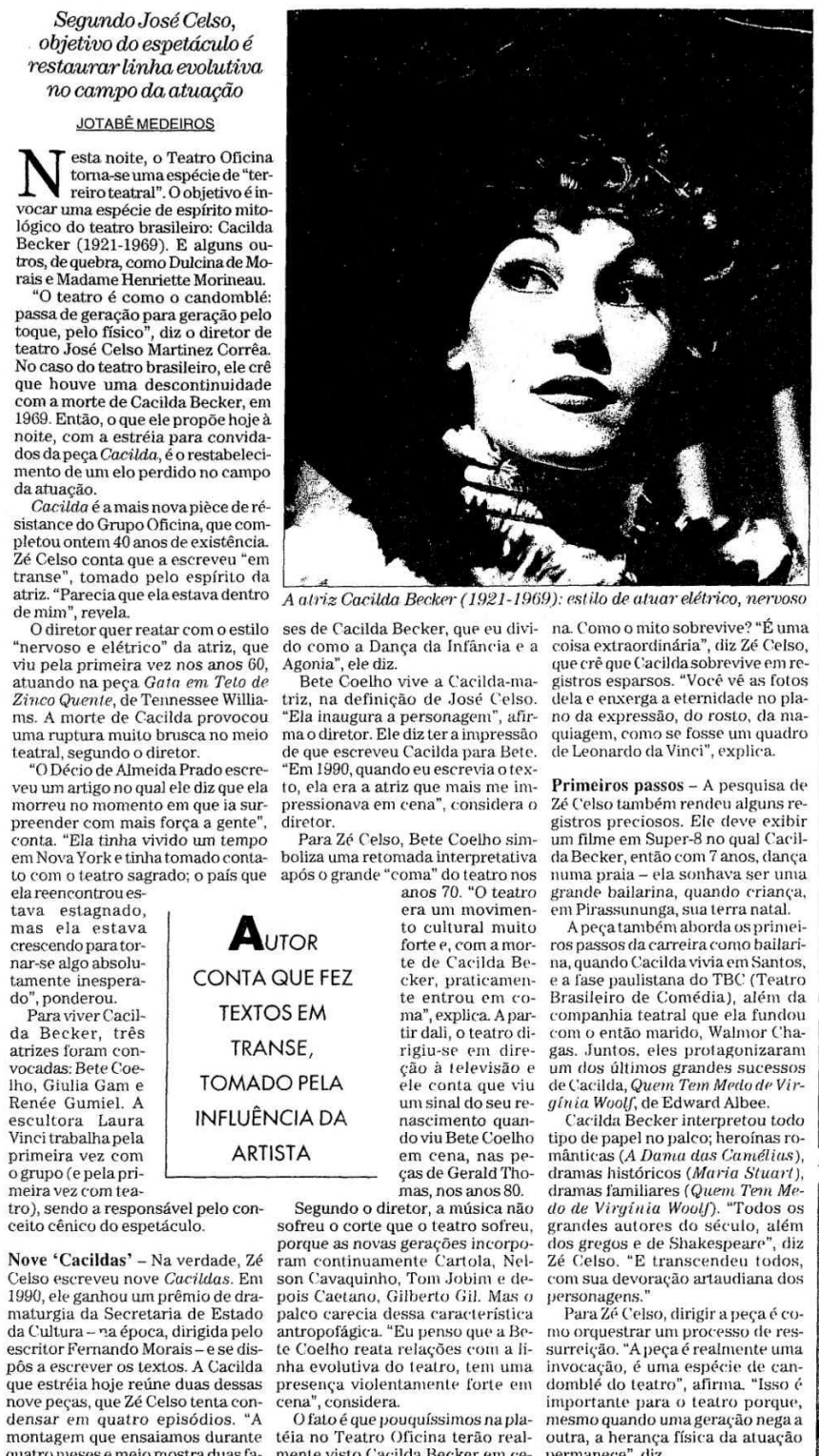

Ninguém substituiu a estrela até agora

Era seu, pormisterioso direito de nascimento, cena brasileira
clugar de prolagonista

MARIANGELAALLVES DELIMA

$\mathrm{N}$

her o vácuo estelar. Era um brilho leatral o dessa extraordinária atriz.
Embora tivesse, ainda que compou政 brada em primeiro lugar pela sua presença no palco. Foi amarda por
um público que era, ele camb gens que aparecem em cena fizer parte cia sua vida. Mas, mais do que o plano biográfico, a peça exalt
umaa certa concepcáo do teatro que

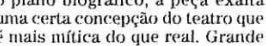

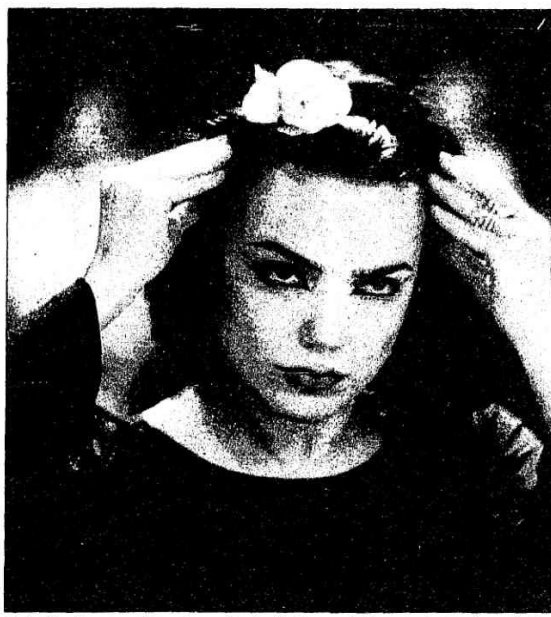
Bete Coelho volta ao palco para viver mito na juventude Atriz lem feito lelevisu. com mais frequêrccia, mas diretor diz que peş

W ineira de Beio Horizonts 1 I 38 anos, a atriz Bete cioc Iro. Com Gerald Thomas, sacutin
palcos nos anos 80, inserindo ur: po de visceralidade que até ent Trmomis

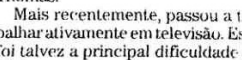
7é C'elso Martinez Corrêa para traze
la de volta ao palco. "Os horários comprumissos da televisão nun ، são fá 'eis dle contornar para a entur
gà que o teatro necessita", diz o dir

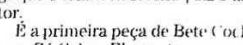

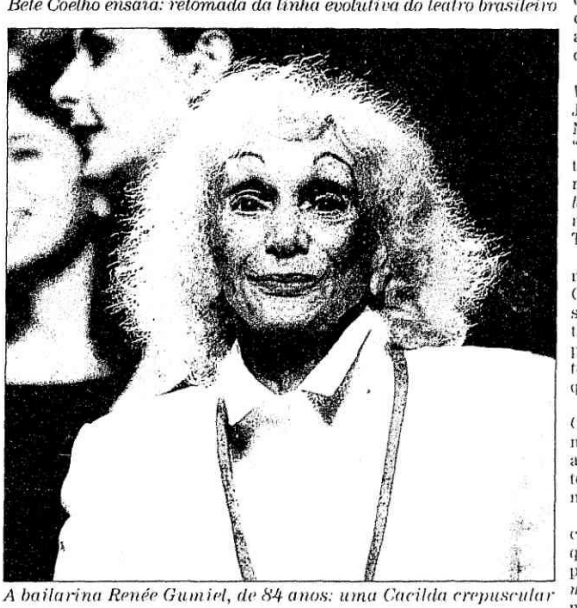

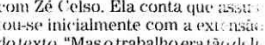

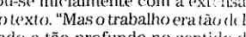
", afîne

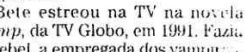

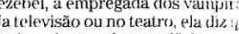

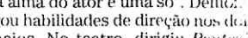

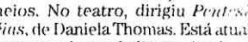
Viancieirantes.

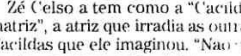
cla quer fazer outras, talvez

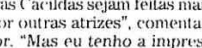

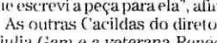
(1) anos, quando passou num

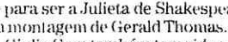

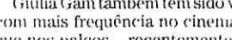

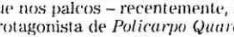

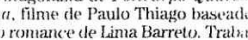

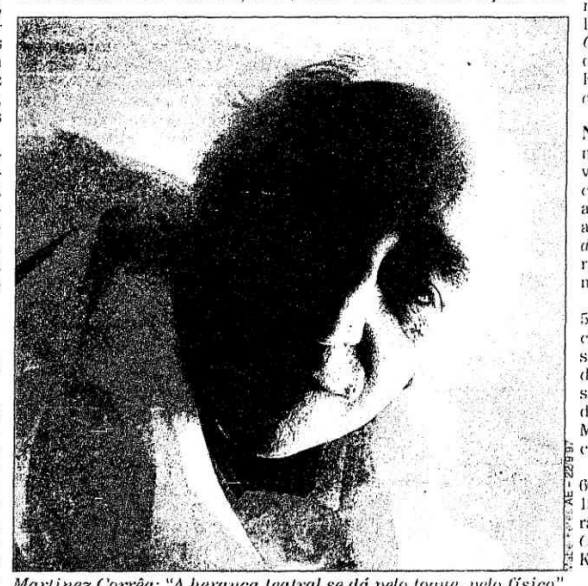

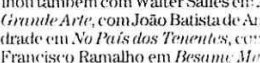
cilv, entre cutros.

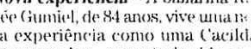

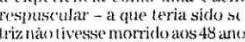

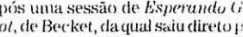

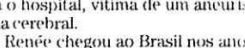

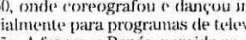

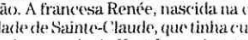

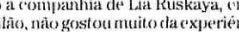

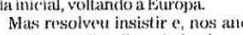

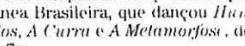
Afora as ( arilltas, o elenco da $p$ (') cilia llelenta e Raut Corter, rolta

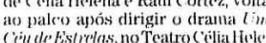
na. () textov, de fernando Bonassi, aur Tala Amaral.

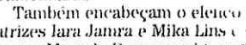

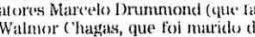

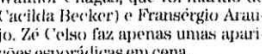

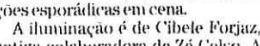

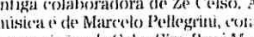

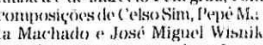
que e casado cem a essicultora Latu ('ueilua terá estréia para o puillico

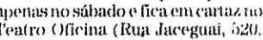

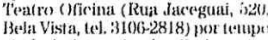

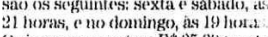

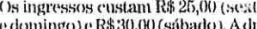

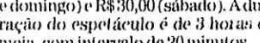




\section{Cacilda 2 (1998)}

\section{Oficina invoca Cacilda em tempo de desesperança} atriz, que nunca truiu sua vocação, para falarde quado de expressar a ira. Mas subntusiasmo meteu cada una dessas etapás à $\begin{array}{ll}\text { pensamentonos indicadores econômicos } & \text { crítica interna. Nunca foi de fácil } \\ \text { assimilaçâo; suas obras resistem } & \text { ao efeito dissolvente da pizza de- }\end{array}$ MABIANGELAALVESDELIMA cartadas como inócuas. O poder pois do teatro. Esprectal $\quad$ de atrito sempre foi essencial para A encenaçẫo que marca agora o

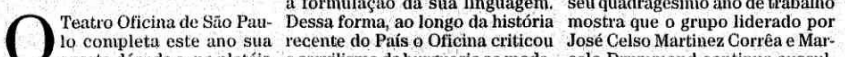
quarta década e, na platéia o o servilismo da burguesia ao mode- celo Drummond continua ausculdesconfortável einsólita dasua ca- lo estrangeiro, a ignorância da tando, sobretudo, a respiração da

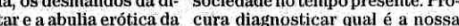
uma geração que cresceu e amadu- civilização de consumo. Seu foco falta coletiva mais grave, contra a receu procurando no teatro alguma
coisa que essegrupo nunca deixou de oferecer. O crí-
tico francês Bernard Dort definiu certa vez, com vocaçẫo do Oficina para fazer 0 "teatro da insurreição". Estava
certo. De diferencerto. De diferen-
tes formas, nem sempre acertan-

IDÉIADEQUE SOMOS RESPONSÁVEIS PORNOSSO DESTINO ATRAVESSA TODA ANARRATIVA do na mosca, o
grupo encarnou foi igualmente rêa com uma estrutura semelhan-
invariavelmente o lado inconfor- zer que, em uma determinada di- te à dos autos religiosos, ema que nista da arte. Foi preciso mudar muito para ca, nâo ficou imune a uma idealiza- salvaçăo e a imortallidade. Sua pepreservar esse cariter insurreto. Poderia ter submergido na imita- bre a imortalidade da alma ou da ropostas que, a seu tempo, signi- çãosubserviente de uma fonte cul- obra. A alma não interessa a um arlítirom un desafio ao sistema po- tural que naoé, por origem de clas-- tista que adota sempre o mote sarlitico e aos costumes vigentes tor- se, a sua. Porvezes exasperou-se e triano de que a existência precede

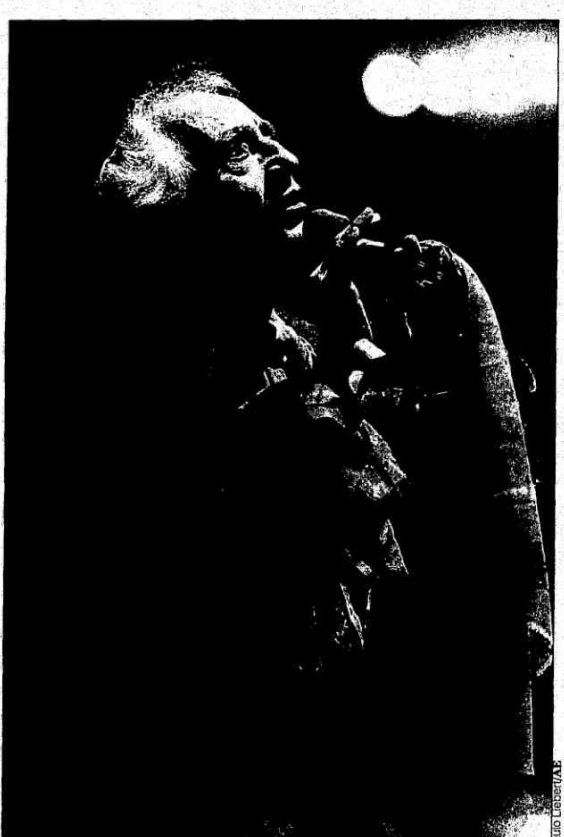
rerimenta a efemeridade da cena
revisa, a cada criação, todos os seus procedimentos. O que o inteum movimente ascenciovar que ha tistas e, de um modo geral, em toconforto em nome do desejo.

Sutilezas - Sua personagem, em contraste com artistas menores do casamento, da vaidade, da prosperidade e do repouso. Todas indicadas com muita sutileza, as veze , para que se configure a espessua do mundo do qual épreciso desrender-se. Naoo há liçöes de moral, mas uma empatia.tão grande com esse espírito exaltado e live zidos, por meio delo, aum despren dimento e a uma aventura maior doque as que poderiam proporcionar as tentaçōes vencidas. Mes. clando à biografia da atriz Cacilda

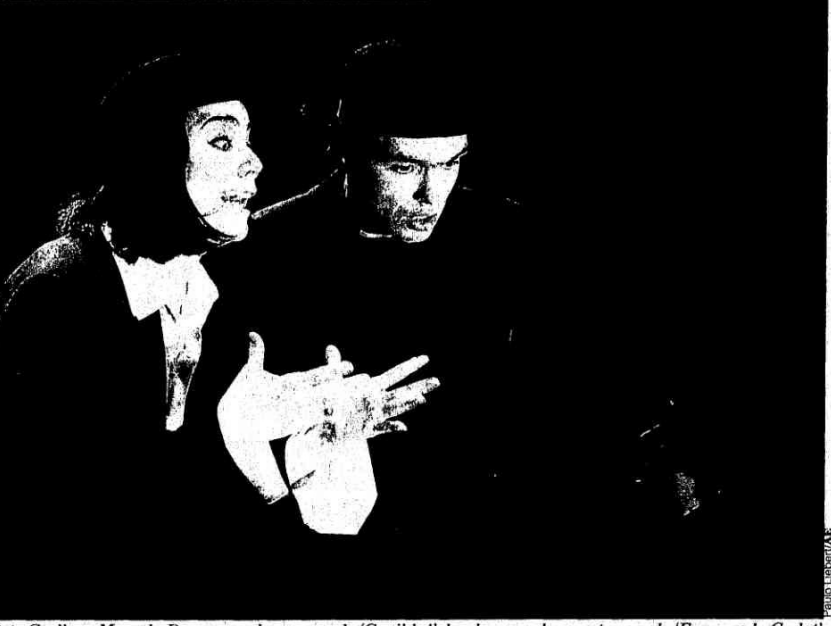

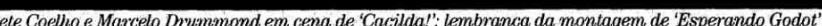

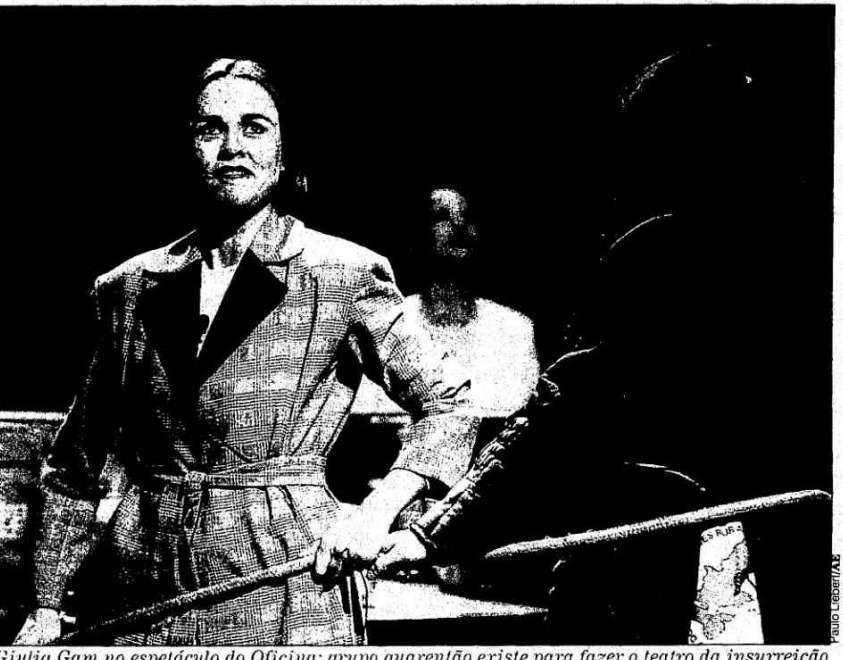

e e da vida é uma das mais esplêndi- do teatro e parece possivel que ou- do a sociedade não divisa utopias que representov, a pecanãose res- des efortes impressōes que o espe- tros indivíduos, dotados da mes- no horizonte, quando a fala coletima vontade e da mesma entrega, va não se levanta além de um muterprete desmedidamente talento- Ao mesmo tempo que nos fala encontrem nesse legado a sua nar- mürio queixoso, éthader. sa. Torna essa nigura o emblema dopoder depres de mitológica ao tempo histórico a a peça nos mostra como essa expe- arbítrio, a escolha e a idéia de que idade do Oficina Mas, para comearte vem produzindo esplêndidas riência alhela se faz carne. Cada in- somos os responsáveis por nosso çar, é preciso reconhecer que expressóes da coletividade e do in- cidente da vida pessoal de Cacilda destino atravessam, de formas di- uma vez mais, o Oficina toca ond dividuo. A persongem Cacilda Becker se ampla, ganta um senti- erentes, todos os momentos da dô. Fala de mesma e inversmente essas ma- repercussão por meio das perso- ca no território do mito, em que se - a uma coletividade de cenho

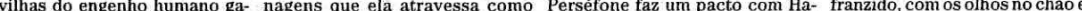
nham vida porque a atriz, sem ne- uma aventura e que a atravessam des para que, periodicamente, a na- pensamento nos indicadores econhuma reserva, empresta-lhes seu como uma revelaçāo de si mesma. tureza se renove. Também a histó- nômicos. Pobre assunto para Zé Celso: procurando diagnosticar qual a falta coletiva mais grave mútua fertilizacäo da obra de arte encontra eco na herança histórica cäo periódica desse pacto. Quan- dias de Sófocles! 


\title{
"Minha irmã era uma mulher multifacetada"
}

\begin{abstract}
CLEYDEYACONIS Especial

Tossa infância, minha, de Cacilda e Dirce, foi muito pouma dona de casa extraordinária,
muito carinhosa. Parece ter nascido para ser esposa. quieta. Minha mãe dizia que chegauma espanhola extrovertida. Atuei assuntos pessoais, intermediava durante 15 dias, Ziembinski assis- namoros e separações. Enfim, tiu e depois convidou-me para preocupava-se com os amigos, lhas e uma mãe, uma mulher ex- rafilha. Falavabaixo, era calada, in- Mais tarde contracenamos na peça de Casa da Mãe Joana. Ela abrigatrovertida. Até ho-

Ela conversava conosco de igual je sou assim, não para igual. Quando mudamos para gosto de entrevisSantos, perguntou se queríamos co- tas, o que chamam mer, vestir ou estudar. Optamos de divertimento por estudar e, por vezes, passamos me aborrece, prefiome. Ela dizia que juntas formáva- ro o recolhimento. mos um banquinho de quatro per- Só no palco solto nas. Nenhuma delas poderia falhar. meas demonios. Eramos muito unidas. Ate hoje Nunca pensei me espanta que tres irmâs de per- en fazer leatro. manter uma racio petiva dicina 0 te tão forte. Cacilda era a líder, seu acontecen por ritor inteligentee mo tempo uma măezona. Talvez ro ano científico, or ser a mis velha das inns, ti- Cacilda fazin $A n-$ nha um instinto de proteção muito jo de Pedra de grande. Com apenas 12 anos de ida- Tennessee Williade ajudava a pagar nossos estu- ms, sob direcão

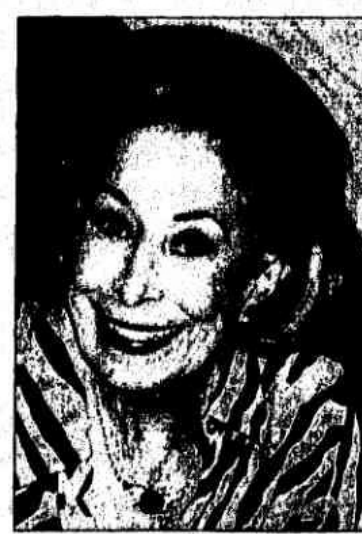
Mary Stuart, ela va hóspedes durante meses. Na no papel de Mary e época da repressão, escondeu geneu no de Elizabeth te perseguida e não saía do Dops. I. Na célebre cena Tirou diversas pessoas da cadeia do jardim, nos di- naquela época, até mesmo eu. gladiávamos num embate feroz. Ao Batizada-Um aspecto pouco cofim da apresenta- nhecido de Cacilda era sua religioção, conversáva- sidade. Era muito católica. Discu-

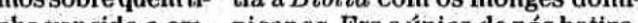
bate. Ora era eu, da nocatolicismo, por opcấ ora ela. Era um jo- pois nossos avós eram da Igreja go aberto e limpo Metodista. entre duas pes- Extrovertida, audaciosa e corasoas que se ama- josa era ao mesmo tempo muito vam frígil. Possú́n uma extremn fragiCacilda agluti- lidade emocional como mulher. nava pessoas ao Cacilda era uma apaixonada. Era seu redor. En- paixão pura. Um mulher nultifaquanto, para cetada o que fazin dela uma pesde ajudava a pagar nossos estu- $\mathrm{ms}$, sob direção de fim de ano da escola e, com is- podia, eu ia assistir ao espetácu- mam uma multidâo, Cacilda que- sem substituição.Insubstituivel so, conseguia amortizar as nossas lo. Vi inúmeras vezes. Sua atua- ria sempre 20 ou 30 ao seu redor. como gente - "perdemos nossa mensalidades. ção era extraordinária.

ria sempre 20 ou 30 ao seu redor. como gente - "perdemos nossa

Dirce, ao contrário, era extremar- Num dado momento, Nydia Lícia não se limitava ao aspecto profis- mo atriz - "Cacilda se jogava nos mente tímida. Casou cedo, com o ficou doente e não pôde atuar. Eu sional. Estava sempre ajudando papéis sem rede de segurança" primeiro namorado e tornou-se sabia o texto de cor e a substitur. os amigos, se necessário, até fi- definiu Antônio Abujamra.
\end{abstract}

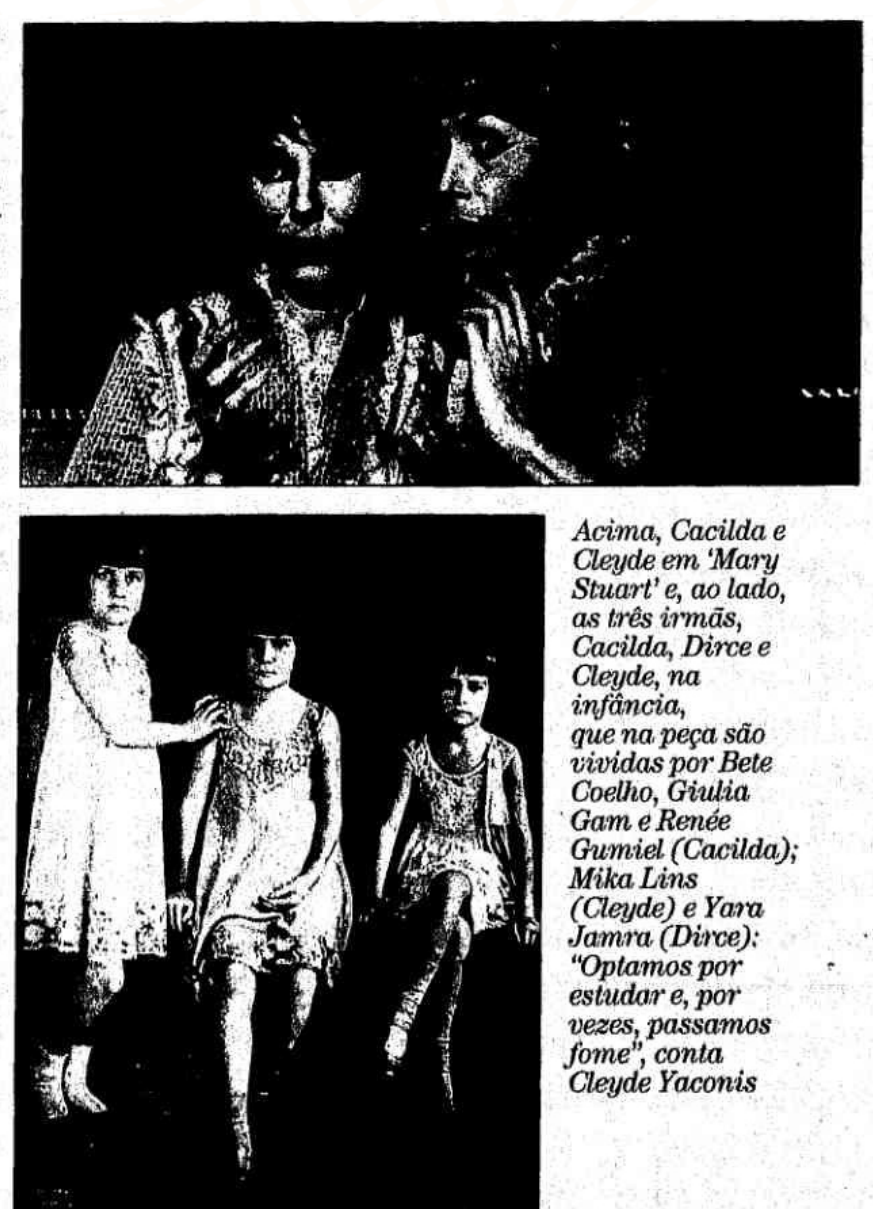


Cacilda 3 (2009)

\section{A estrelinha almejava a constelação}

Peça do Oficina explica muito bem como energia e instinto acompanhavam o início de carreira da grande atriz Cacilda Becker

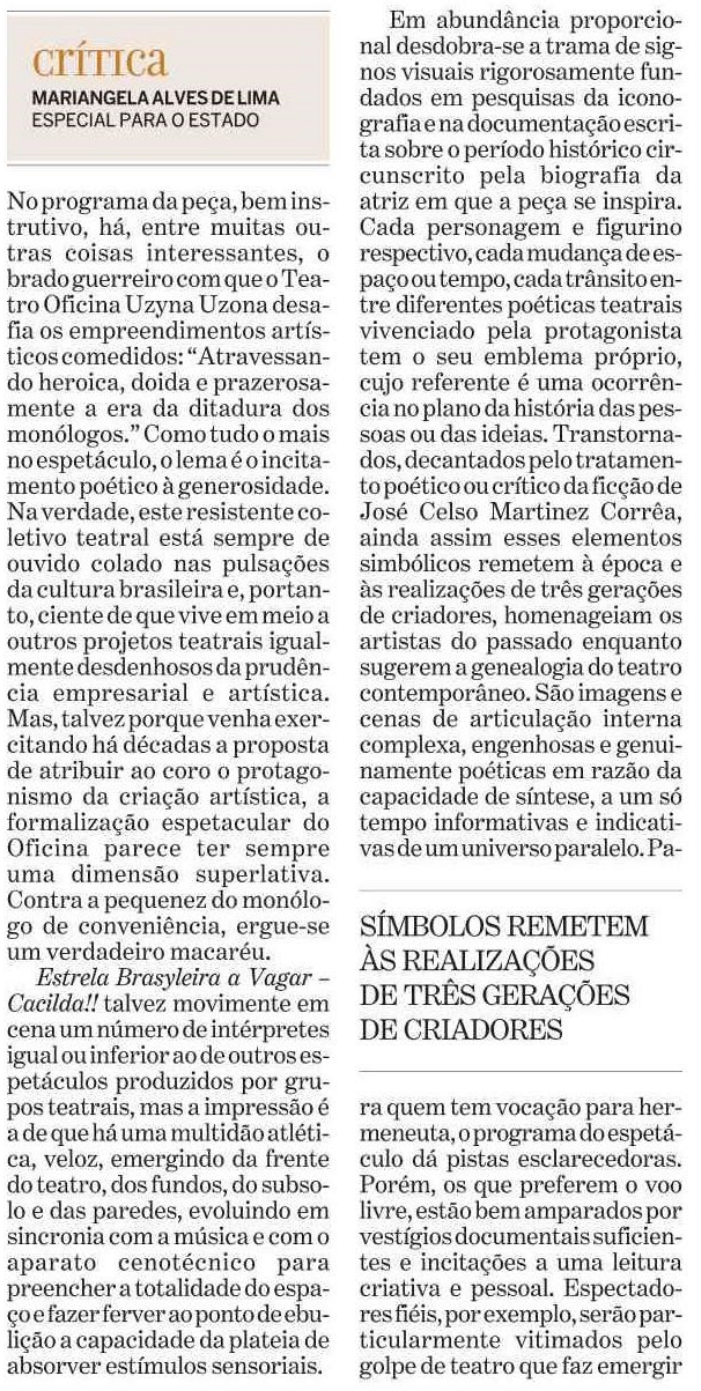

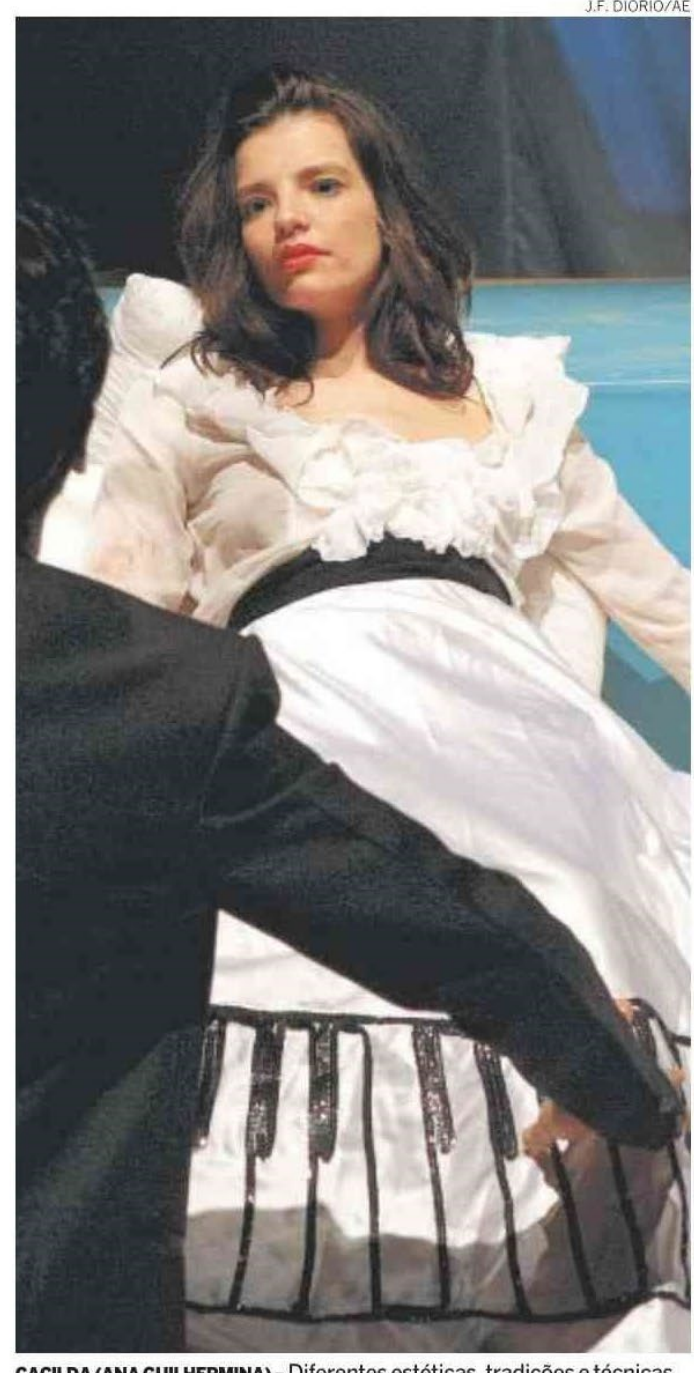

CACILDA (ANA GULLHERMINA) - Diferentes estéticas, tradições e técnicas deumovodourado, agoranopapel de Sérgio Cardoso-Hamlet, so. Pois não é que vimos o menino crescer? Pois esse laço tribal, íntimo, entre um grupo de meio século e seu público, tambémintegraa

de encenação. De qualquer forma, a julgar
pela possibilidade que o espetáculo oferece de transcender o particular, a hagiografia não é vocação do Oficina e a estrela que preside este espetáculo, embora vague pelos céus aspira ao todo maior da consaspira aça.

TRAMA DE SIGNOS VISUAIS RETRATA RIGOROSAMENTE O PERÍODO HISTÓRICO

Oestranho, aparentemente errático e, sobretudo, livre cainho percorrdo por Cacilda fância até as companias profissionais cariocas, passando pelo teatro comercial e pelos grupos amadores de vanguarda, tem, na perspectiva do espetáculo, o impeto da energia gue, não separa e age movida pela sedução do desconhecido ou pela convicção de um destino artístico, a protagonista experimenta a multiplicidade, encontra diferentes mestres. Mais tarde, tornando-se figu-
ra de proa do moderno teatro brasileiro, a atriz que inspira o espetáculo levará consigo como um enxoval, na interpretação que dela faz o Oficina, uma mescla única e uma abertura
singular para todas as verten- es da cena. Para a fulguração cartilhas estéticas diferentes técnicas que a mocinha dos nos 40 absorve e leva adiante como o "cordāo de ouro" que alinhava os episódios dessa arrativaetem, em sua composçaa, três coresprimáriasetoHá muito tempo - basta dier que foi antes que os brianos $o$ fizessem - o Oficina introduziu nos palcos da classe média culta a discussão séria sobre os emas da cultura de massa e da endência dentro Drecingu fez alianças até então improváveis, separou criticamente as noçôes de "massa" " "popular" e malhou o que, de um ou de outroladodaarena cultural,julgava impositivo e, portanto, um Na trajetória do grupo, só gora essas partículas em suspensāo começam a amalgamarse em uma espécie de camada sedimentar.Outras Cacildas se somarão a esta, promete o provel que novos veios in e possinais irrompam para transtornar o inconsciente desejo de harmonização desta fase de noviciado. Enquanto isso, com uma tonalidade pouco usual na raço rosamente harmoni amorários. Pode ser que de uma vez por todas, tenha passado o tempoemqueeraprecisodepenar e fazer uma canja com os Serviço

- Estrela Brazyleira a Vagar Cacilda!! 300 min. 16 anos. Teatro Oficina (350 lug.). Rua Jaceguai, 520, tel. 3106-2818. Sáb. 


\section{Os Sertões. A Terra (2002)}

\section{'Os Sertões' faz apelo à consciência}

Egrupo de Zé Celso domina como nenhum outro a plasticidade do espaço teatral MARIANGELAALVES DELIMA

$\mathrm{O}$ al para o Estado

eatro Oficina faz coincia primeira parte de $O s$ sertões com a comemoração do centenário da publicação da obra. Em vez de sobrepor palavras sobre palavras, a encenação cinaenfatizarocaráterdepresentificacão do teatro - as palaser e ou de- vés das aberturas do edificio para um 列 vro" terão a oportunidade de ou- poente nem o céu nublado do Be- trumentos de criação. São ovocavir e sentira potência escultorica xiga. O entorno faz parte de uma buário e a sintaxe do teatro que daescritadessaprimeiraparte da rigorosa logistica espetacularque se tornam instrumentos familiaobra. São trechos do livro, às ve- associa o texto centenário ao respormeiodesse intróito: a prezes em unissono, musicados ou meioambientedessetempoedes- paração corporal, as vocalizaassumidos por personagens sin- selugar. A ordem de grandeza que ções humanas que se tornam aogulares que amparam solidamen- Euclides conferiu ao sertáo por poucossimbolicas,passandoainficalohín

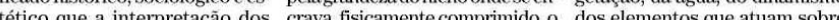
criadores espéćchas de entrever a vas- tornada afetuosa pela presença As atualizaçóes adaptações a que o grupo habitualmente submete os textos clássicos com o intuito de evidenciarpossibilidades analógicas, cederemlu-

\section{TExTode} EUCLIDESSEDUZ ATÉQUEMNÃO LEULIVRO de entrever a vas- tornada afetuosa pela presença
tidão da cidade.
de crianças no elenco, funciona Dura pouco a por assim dizer, como glossário placidez contem- do léxico teatral e convite par plativa. Uma vez prosseguir em direcão ao territốstruturada essa rioinospito do sertâo e ao mortrepresentação da ciniodeCanudos. Figura sobrefimorfologia da ce- gura, a recepção que o espetácuna, propondo lo dá ao público também se am uma relação per- parano significado dotexto origmanente entre nal: "Acredita-se que a região inLesiturapor treopasto atureza tão ́ntegra que talvez maturgiacriadapelo diretor seli- capedra fecundandoaterra" não suportasse a exploracão de ga também com impeć́vel lógi- Sobre essa suspensão de júz hiatos entre significante e signifi- ca, ao procedimento construtivo contida no "acredita-se" a ence cado. É una decisão sábia por- adotado pelo autorde Os Sertôes, nação vai sobrepondo imagen 政 rá do espetáculo seduzido pela $t a$-tendo antes nos advertido alternadamente pela acão moduforça e pela beleza do texto. quesetratada denúnciade um cri- latória dos fatores externos coAlém disso, um extraordinário me-que Euclides da Cunha pega moachuvae ovento, pela estraté esforço de transititeração dramati- pela mão o seu leitor e o instrui e gia das raizes, pelo modo como o zaamorfologia do território abar- seduz para enfrentar a dimensão sertanejoresisteeaprendearecocado pela obra, desde a forma ca- terrivel do episódio que vai re- nhecer e a aproveitar o que há de pilar dos veios aquáticos até ore- construir. Domesmomodo, osin- propicio a sobrevivência. Os canlevo, a vegetaçáo e as variaçóes - tepre climáticas. Una das operaçós tos namertais dotexto, que a de meiodoestímulosensorial,éreassumida pelo espetáculo que encontra signos teatrais concisos, impactantes e sedutores em cada etapa dopercurso.

Quem quiserse aproximar desse espetáculo pela vereda marginale serena da fruiçãopassiva, tera com que se ocupar por um breve tempo. Nos seus mais de 40 anos de trabalho, esse grupo lideradopor José Celso Martinez Corcea pacoteatral exteriorà caixaitaliacos os materiais mais simplese tirar partido do valoralegórico da figurahumana. Tudoébonitonessa encenação, com aquela qualidade peculiar e pungente do efeito estetico arrancado, pela força daimaginaçăo, às substancias elementares como a água, o fogo, o

\section{PSICODINÂMICA}

"O desafio tançado por James Hollis é cheio de
compaixão e inspiraçăo. Ele quer que tenhamos sucesso."

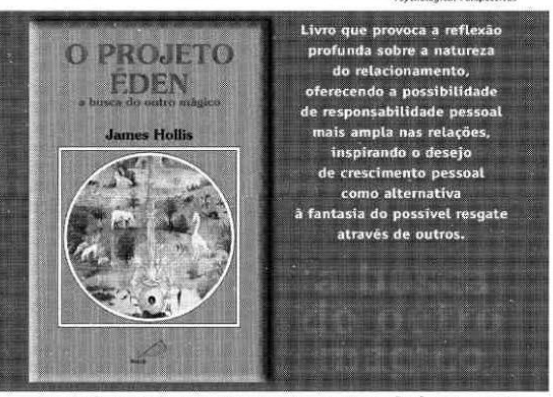

zação doelenco comopúblicoce- plos dos sentidos entrelaçados ebram essas vitórias esporádi- anulando a seqüência cronológicertões'. De i- Euclides da Cunha. entre o espaço cênico e a platéia cação e o apelo feito por Eucli- Direção José uma cuia dechá dejurema, trânsi- des da Cunha à consciência dos Celso Martinez Corrêa. to simbólico do projeto de imer- cientistas e governantes. Falan- Duração 3h30. Sábadoe são ritual que o Oficina retoma do do aqui e do agora o Oficina domingo às 18 horas. em todos os seus espetáculos. A apela à consciência de cada um $R \$ 30,00$; segunda, violação da terra pela economia de nós. A idéia de polis que se de- às $14 \mathrm{~h} 30$, sessão extra, extrativista, a correspondente senha ao final desse espetáculo $R \$ 10,00$. Teatro violação dos espaços de germina- parece não ter centro. Estamos Oficina. Rua Jaceguai, çãocultural pelosmacroempresá- assimpreparadosparaoprotago- 520, tel. 3106-2818. rios da comunicação são exem- nismo coletivo de $\mathrm{OHomem.} \mathrm{Até} \mathrm{segunda}$

Sênior plus: banco bradesco Danco itaú • br distribuidora - grupo $\mathrm{cms}$ energy • ministério da cultura - prefeitura do municipio de são paulo - secretaria de estado da crisa do brasil - sênior: accor - banco bba Conton - diário de são paulo $\bullet \mathrm{dpz}$ - ernst \& young • folha de s.paulo - gazeta mercanti (ares servicos de segurança $\bullet r$ sistemas • valor econômic - pleno: abril • bloomberg do brasil • cma $\bullet \mathrm{cpm}$ - fundaça genéricos - grupo predial • grupo vr - itaú seguros. Iemos editorial • levy \& salomão advogados petroquimica uniáo ripasa s.a celutose e papel • secretaria de estado da cultura - secretaria municipal da cultura $\bullet$ shopping jardim sul • sodexho pass - master: american express foundation - bm\&f - camargo corrêa - carta editorial cia. suzan de papel e celulose $\cdot$ dm9ddb - ecentry • editora d'ávila - faber-castell - gusmão \& labrunie - propriedade intelectual $-i b m e c$ - linklaters\&alliance - ornare • pirelli • rádio cbn - shoppings paulista - west - shoza plaza sul pátio higienópolis - souza cruz - tufani, reis e soares - vedacit - votorantim - white\&case patrocinio de exposições: deutsche bank - itautec philco - petrobras - pricewaterhousecoopers - telefônica • patrocínio de espaços: bayer s.a. • itaú personnalite - shopping villa-lobos - patrocínio do baile de máscaras: credicard - cyrela - grand hyatt hotel $\bullet$ apoio cultural: actech • alpha vision • alves tegam - century consulting - chandon. clear channe outdoor - consulte arte \& decoração - dtcom direct to company - flores online - graphbox caran - hines - itaú cultural • kpmg auditores independentes - mckinsey\&company

- paulista s.a. empreendimentos - publicrono - rádio bandeirantes - rádio eldorado - revista de higienópolis $\bullet$ revista cult . - seven english espanor - shopping center norte - skillingles-espanhol - su america - tintas international - unibanco - usina sonora - vinhos salton • yázigi - parceiros institucionais: apae de são paulo - assembléia legislativa - caps - centro de atencáo psicossocial - casa de saúde de sấo joão de deus - cececo - sáo joáa de deus - cecco - policia militar do estado de sáo pauto secretaria de seguranca pública de segurança pública

\section{hoje o mám vai expor os seus agradeci- mentos.}

obrigado aos parceiros do mam que, durante o ano de $2 A A 2$, possibilitaram o acesso à arte ara mais de 3AAAAA pessoa. um exemplo de cidadania e de incentivo à educaçẫo e cultura deste pais.
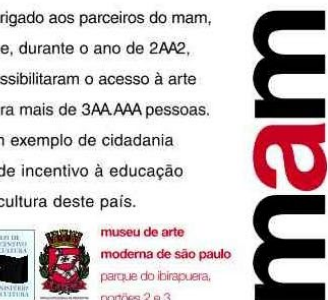


\section{Os Sertões. O Homem (2003)}

\section{'O Homem' envereda pelo caminho da atualidade}

Aspecto poético da obra
de Euclides da Cunha de Euclides da Cunha
ganha ênfase em peça que evoca a memória

MARIANGELA ALVES DELIMA Especial para o Estado

rata-se de um livro e não
de teatro. Feita a uma cerde teatro. Feita a uma cer-
ta altura do espetáculo encenado agorano Teatro Oficina, a afirmação, em tomjocoso, brinca com as refrações da tarefa a que

se propôs. Centenário, glorifica-

- do e ainda inacessível para a maior parte dos brasileiros, o livro de Euclides da Cunha é, do mesmo modo que outras obras sal, ummonumento. Como todas as exegeses contemporâneas feitas noâmbito dos estudos acadêmicos, a teatralização tem implí-

- micos, a teatralização tem implicito o objetivo de popularizar $O s$ Sertões. Ainda que fora de moda,
o termo popularizar - onde se o termo popularizar - onde se

- embosca a ideia de que o povo de dividir alguma coisa que só os privilegiados possuem. E esse livro tem sido, como tantas outras coisas belas que a cultura brasileira produziu, privilégio dos letrados. Atravessemo-lo, provoca o Oficina. Énosso.

Pertence-nosenãoéummonumento cuja finalidacle se esgota conter modernizada, evocam a experien- sobre a morfologia, as etnias e as cia do espectador om a diversidade do País. Um instrumento ma certa linha melódica repetida, ritmos familiares vão funcioando para a inrodução do tema a formação étnica das diferentes

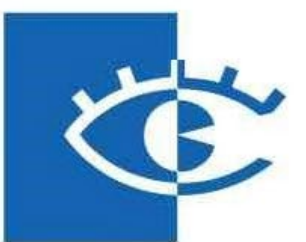
etapas históricas nacionalidade. Alguma coisa sabemos sobre o gaúcho e opaulista, a paisagem dos gerais, o efeito dos contrafortesmon-
tanhosos sobre o tanhosos sobre o
clima, as regióes clima, as regioes florestas tropide fazer, convidando à participa- cultura demassas e o ensino reguào, o espetáculo evoca a memo- lar tornaram familiar é reaprovejnarrativa cujo cerne é o destino mosfera de saber compartilhado. dacoletividade Eessaéumaope- Comasuaexperiênciademais de racão critica deliberada sobre o 40 anos, o Oficina não presume a fetiche do livro ou do livro como ignorância dos espectadores pioneira, ousada, profundamente brandoaospoucosnozesmais duconhecimento do século 19 , a riacomque Euclides da Cunhare-
Deummodoque só oteatropo- cais. Tudo oque de algum modoa etiche. Enquanto investigação Só então o espetáculo vai que-

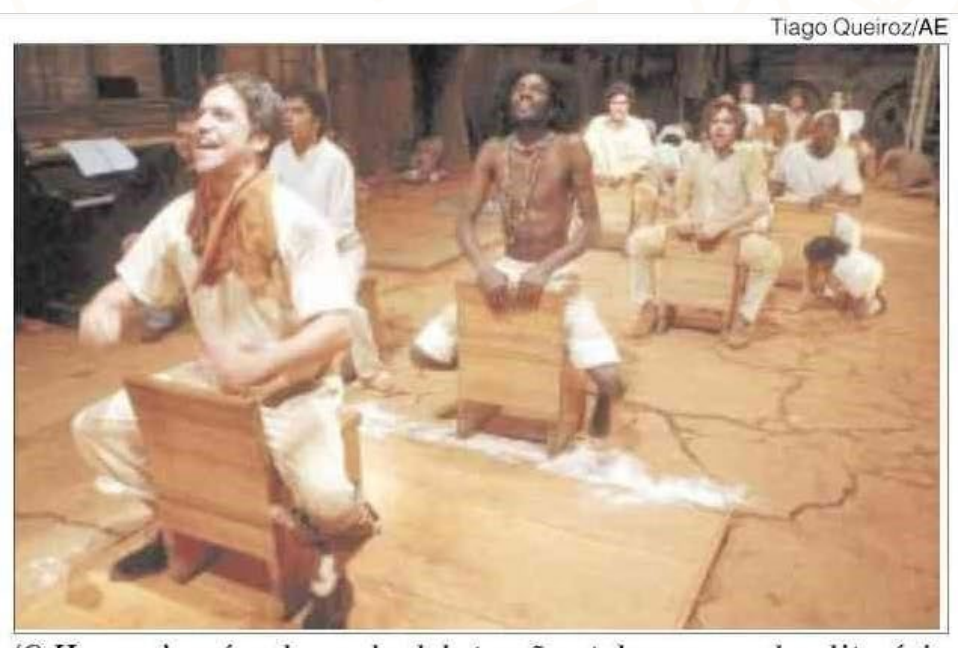

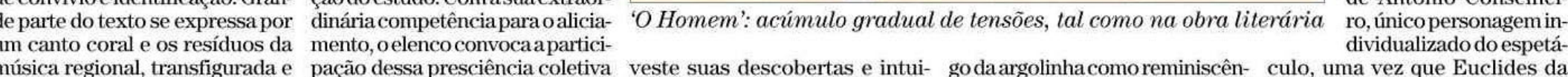

a teatral em capítulos, o Oficina percorre a primeira parte de $\mathrm{OHO}$ mem. Estão delineadas nesse espetáculo as duasforças para o embate da última parte do livro. Norte e Sul com suas diferenças explicitadas no campo da história e da antropologia aprontam-se dramatica epronte. Desenhou-se "comón un pe limper como un paiapsesto, a consciencia imperfeitados matutos.... O espetáculo abre alas para a entrada de Antonio Conselhei-

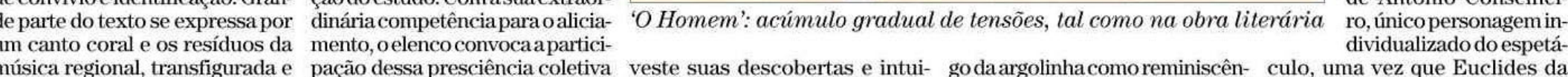

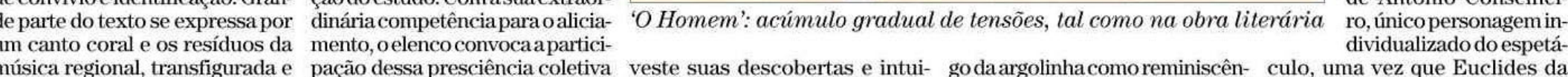

música regional, transfigurada e pação dessa presciência coletiva veste suas descobertas e intui- godaargolinhacomoreminiscên- culo, uma vez que Euclides da
modernizada, evocama experiên- sobre a morfologia, as etnias e as çóes. Também ele foi manipula- cia dos combates das gestas me- Cunha(representado por Marce-

dor da "metaquímica sonhadora" dosfictícios" e esse caráter de experimentalismo, fascínio pelo objeto de estudo e resultados incertos é aproveitado para enfatizar o aspecto poético de Os Sertões. A constituição histórica e étnica de cada região, as interações entre a geofísica e a cultura são em ma-se a paisagem por meio das palavras e dos movimentos, insinuam-se os processos de aculturaçáo por meio da música e promove-se a sintese com a figuraa que o texto se refere.

Eo espetáculotraduztambém, como não poderia deixar de fazêlo, o fascínio pela imagética que contamina até os leitores deliberadamente "científicos". Abromélia incrustada no chapéu sertanejonas raras ocasiōes festivas, ojo- cia dos combates das gestas me- Cunha(representado por Marcesas do modo de cavalgar do Sul e de condutor do jogoe de observado Nordeste, o aboio e o estouro dor neutro do universo que ão, na perspectiva do espetácu- criou. José Celso Martinez Cor-

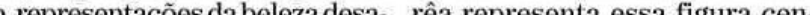
. ida de popula comcertez háumapreocupacões. Cenus celebrizadas pela cão logistica júlilicando cossa

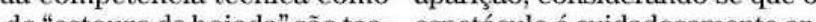
" tha espetáculo desprende-se do su- ridades eacúmulogradual de tenporte literário e envereda por sões, tal comooplano daobralitenea autonoma. Do mesmo modo selheiro parece-nos uma antecicomose is acta, as vezes comiro- pacao de outro espetaculo.

nia, de afirmações etnocêntricas, a encenação se subordin mansamente aos trechos que onsidera insuperáveis. A letra igorosa e o espírito especulatio de Euclides da Cunha são gualmente bem servidos.

10. Teatro Oficina. R. Jaceguai, 


\section{'Sertões' solicita atenção e reverência}

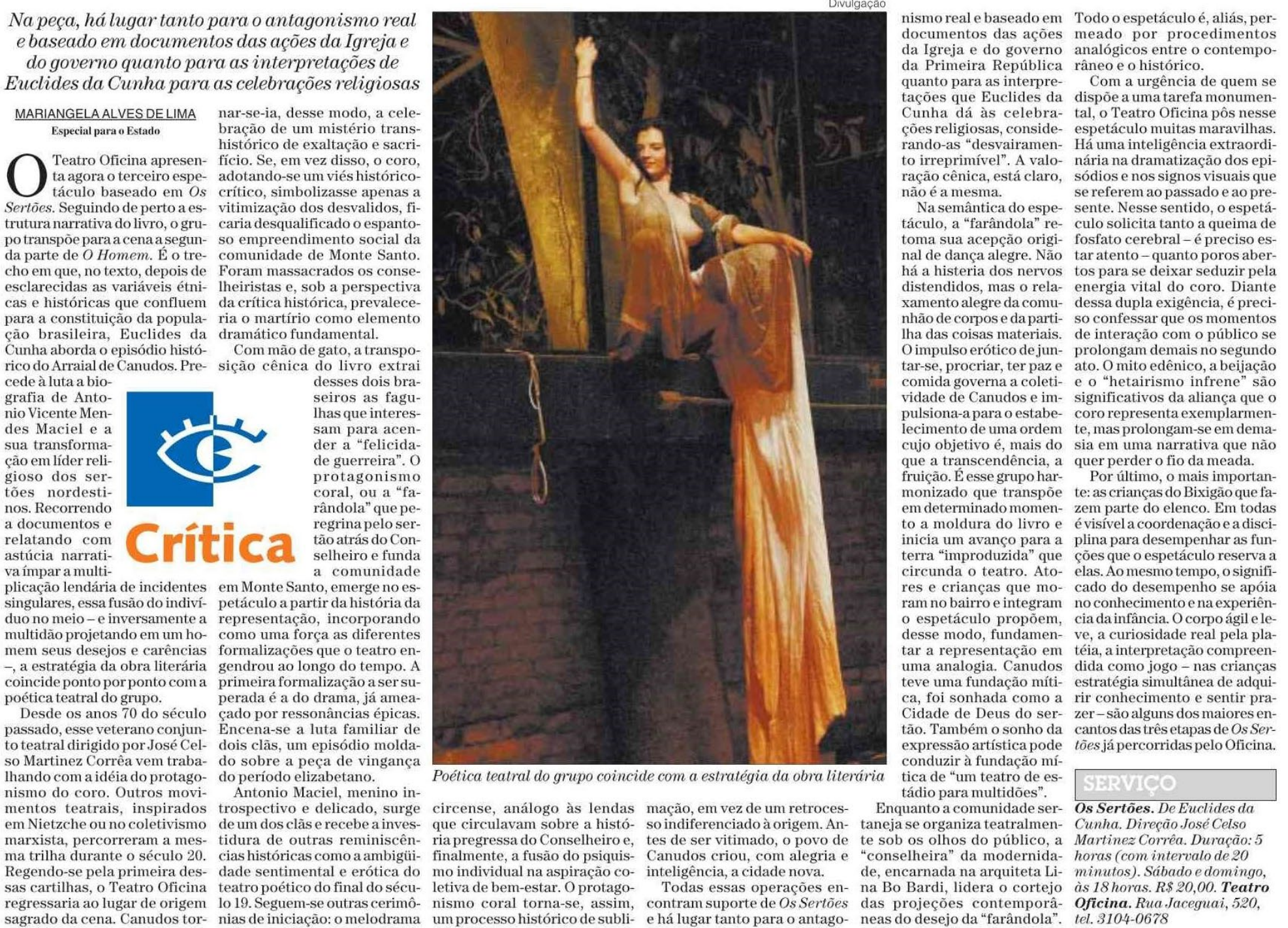


Os Sertões. A Luta (2006)

\title{
Oficina, uma aventura intelectual sem paralelo
}

Impossível não destacar a investigação, com inteira liberdade, de Os Sertões, a monumental obra de Euclides da Cunha

\begin{abstract}
Mariangela Alves de Lima
ESPECIALPARA O ESTADO

Foi-seoprimeiroqüinqüênio do século XXI e Canudos não se rendeu. Na soma final do ano em uma cidade tão grande coria de cada espectador separa em meio ao que foi possivel ver, umpunhadode coisas boas retido na peneira por onde passaram muitos espetáculos. Para cada observador do panorama portância definida peles importancia definida pelas cirpelo critério misterioso do gosto, por uma identificação vocacional com este ou aquele tipo de teatro. De qualquer forma quem quer que tenha acompadateatral da cidade nos últimos anos, não ficará indiferente à proeza do Teatro Oficina ao encenar, este ano, o último episodio de $O$ S Sertôes. Por uma questão de justiça, antes de tudo, ê conjunto teatral que é a um só tempo emblemático da arte aguerridae da feição aventureira da investigação puramente 2006, uma aventura intelectual sem paralelo no nosso panora- seu público uma obra literária que o ensino formal, por razões que mereceriam tratados, não vou, admirado, dianteda estatuEuclides da Cunha, e investigou, com inteira liberdade, a diferença entre as matrizes da ciência social e da arte no final do século XIX e os novos movimentos sociais e artísticos do
início do século XXI. José Celso MartinezCorrea, aplicando sobre o texto o rigor exegético
\end{abstract}

dos filólogos, comprovou no culo denecessidade entre o estilo de Euclides da Cunhaeaintenção militanteda bra.Edetal ordema complexiáculos do Oficina que, mal enpiclo, comecam a ocupar na historiografia teatral, $o$ gar proeminente que o livro , etando do Oficina, contudo, é pouco provável a transfiguração do bode orgiástico em

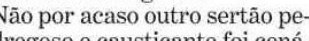
rio, este ano, das aventuras de D.Pedro Diniz Quaderna, protagonista de A Pedra do Reino. Também longamente meditatho, oespetáculo Antunes Fiçocênica deuma dasobrasprimas da literatura do século pasBR-3 FOI PENSAMENTO MAIS AVANÇADO

SOBRE O ESTADO DO

NOSSO PAIIS

sado. Postonasequeência cronoogica, olivrode Ariano Suassusertão" da nossaliteratura. Dialogando com a obra documental de Euclides da Cunha o romance de Suassuna é, tal como
o de Guimarães Rosa, a paisagem introjetada de onde brotam as miragens da cultura ruCentro de Pesquisas Teatrais doSESCanarrativa do protagonista é epopéia, e não drama. O zação essencial em que um ator
dá voz e evoca as imagens da história que quer contar. Teatro feito com pouca matéria e

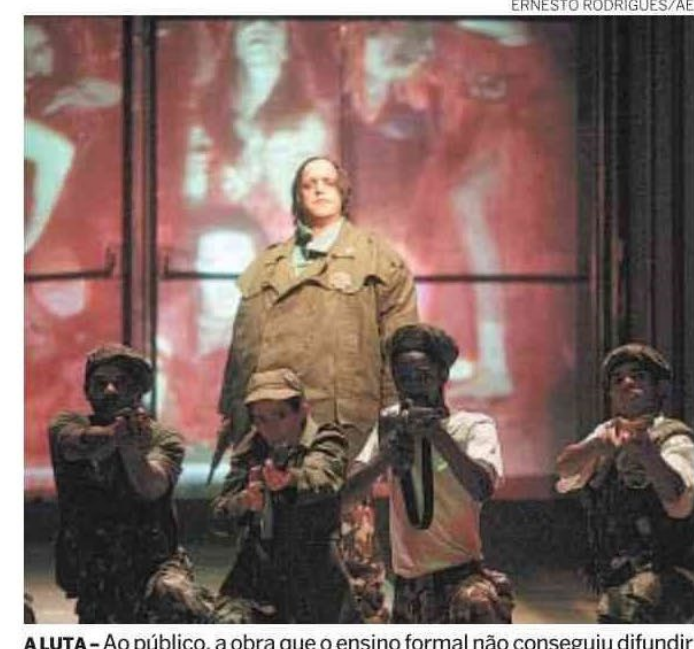

lista.Ameaçada de extinção pe-

lalinguagemicônicaepelosgru-
nhidos da comunicação eletrô- axiais em profundidade
até que revelem o máximo de nica(rápida eutilitária) alinguagemliteráriaencontra agora no teatroumpaladino. Antes oteatro era, como o cinema, um frearte da qual desejova de uma der-se de uma vez por todas. Ao lado disso a modernidade da linguagem cênica, desde o rompimento com as variaçōes dramáticas do seculo dezenove, continua sendo uma atrares. Vários desses pontenadodarenovação dramatúrgica do
final do século dezenove e do século vinte entraram em cartaz por meio de espetáculo altura das provocaçoes textrabalho dirigido por Gabrie Villela, foi executado com agravidade cerimonial de um rế-

muitas palavras o espetáculo breUtopia, oesplêndidolivrode do CPT é uma espécie de retor- Thomas More que dormitava no a origem do teatro ocidental entre outras celebridades desbilizou por muitos anos para a resdehoje. Diricido por Moacieconstrução dos seus espetácu- Chaveso trabalho datrupe Pésos, signos visuais derivados do sima Companhia apoiava-se, an epertório inconsciente. tes de tudo, nas possíveis foraao é a primeira vez que o CPT mas de enunciação de um texto. do livro ao moño ó a mescao Também do Rioveio outro do cisa teatro. Em Gilgamesh, espetá- Horas. Nocasodesta peçaescriulo de 1995, a escrita corres- tapelodramaturgoespanhol Jopondia, no espetáculo, à busca sé Sanchis Sinisterra as persode permanência do herói épico. nagens definem-se pelo modo
É um tema que o teatro de ago- como concebem a literatura. não sabeme te audosismo ouconfiancasincena resistência da cultura leAlém do Oficina e do CPT veio do Rio de Janeiro um do melhores trabahos do panor a pands ta, una meditaça cheia de invenções teatrais so- quiem e esse andamento solene descobriu, sob a descrença, o Tapa levou à cena Camaradagem, peça de August Strindberg em que se desenha a insrragmentação de espaço e tempo que se tornaram caracterísda por Eduardo Tolentino de Araújo a encenaçãoé tecnicamente perfeita como são todas as produçōes do grupo Mas, mais do que isso, tratase de um teatro excepcionalque usa para radiografar os . masculino e o feminino. Datramaentreesse "serliter se a riqueza inesgotável de um alianca que quase chegou a se considerada anacrônica. Talvez exista por sob esse interesma, e não mais como fonte de inspira mais como lonte de uma solidariedadedeambienta- marítimas de Eugene O'Neillé rajoso coletivo teatral dirigido po Andre Garolli. Tambémes dentro possibilidades estéticas.

Sa Paulo recebeu, durante 0 , a visita de prestigiadas companhias estrangeiras. Ditiva sul-africana Sizwe Banzi est mort cativou até a exaltaum público saudoso das coisas simples. E o pro. táculos tão bono cinco espeimples existência, pela sua tem os clichês com que a imprensa até hoje mimoseia os ex-soviéticos. Sociedades que são capazes de produzir e susifestapialiosomao, apurotécnicucia, bomgosceitual estão fazendo alguma coisa que vale a pena imitar. Pois são os visitantes russos que sugeriram o mote amargo tos, balanço. Nos, paulistaobre á́ s empreendimentos teatrais do país. $B R-3$, spetáculo longamente prepaado pelo Teatro da Vertigem perturbador obs avançado nosso país em particular (e de todos os países pobres de um modo geral) ficou em cena por apenas dois meses e pode ser sto por pouca gente. E era o ava ver para acidade precis mesma, para compreendereepara, talvez, comecaradesprezar as coisas que passam a amar as que não passam. Deino mesmo rio que continuamente poluímos o que há de de e poder de realização. que foi, sem dúvida alguma, 0 xamos sangrar e dissolver-se 
Taniko (2008)

\section{Celebração comovente do Oficina}

Com o belo Taniko, grupo incorpora 50 anos de trajetória ao tema da imigração

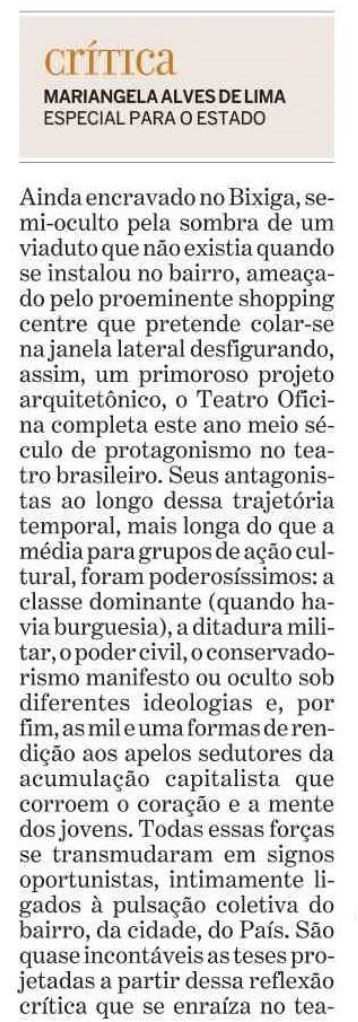

tro, mas que se expandiu pela arquitetura, inspirou projetos de urosanização, fomentou da, repercutiu na músiaganda, repercutiu na música, nas
artes plásticas e sobre a teoria daarte cênica. Teatro social na prática na teoria, o Oficina tambem um centro de formaApesar dessa vocação para c combate fazpartedacelebração da meia-idade um espetáculo quase pacífico. Não inteiramentepacifico no que dizrespeito às intençoes, mas apazirespos uma das formas do teatro clás“TRANSZÊNICO”É UMA BOA DEFINIÇÃO PARA ESSE TRABALHO FRONTEIRIÇO

sico japonês. Sempre atento ens fatos e as redes tramada ciente, ogrupo soma à celebração da sua efeméride íntima uma outra memória, a da chegada dos primeiros imigrantes aponeses ao Brasil. Do mesmo culos anteriores, os ritmos e os mitos das culturas regionais, desta vez recorre à geometria

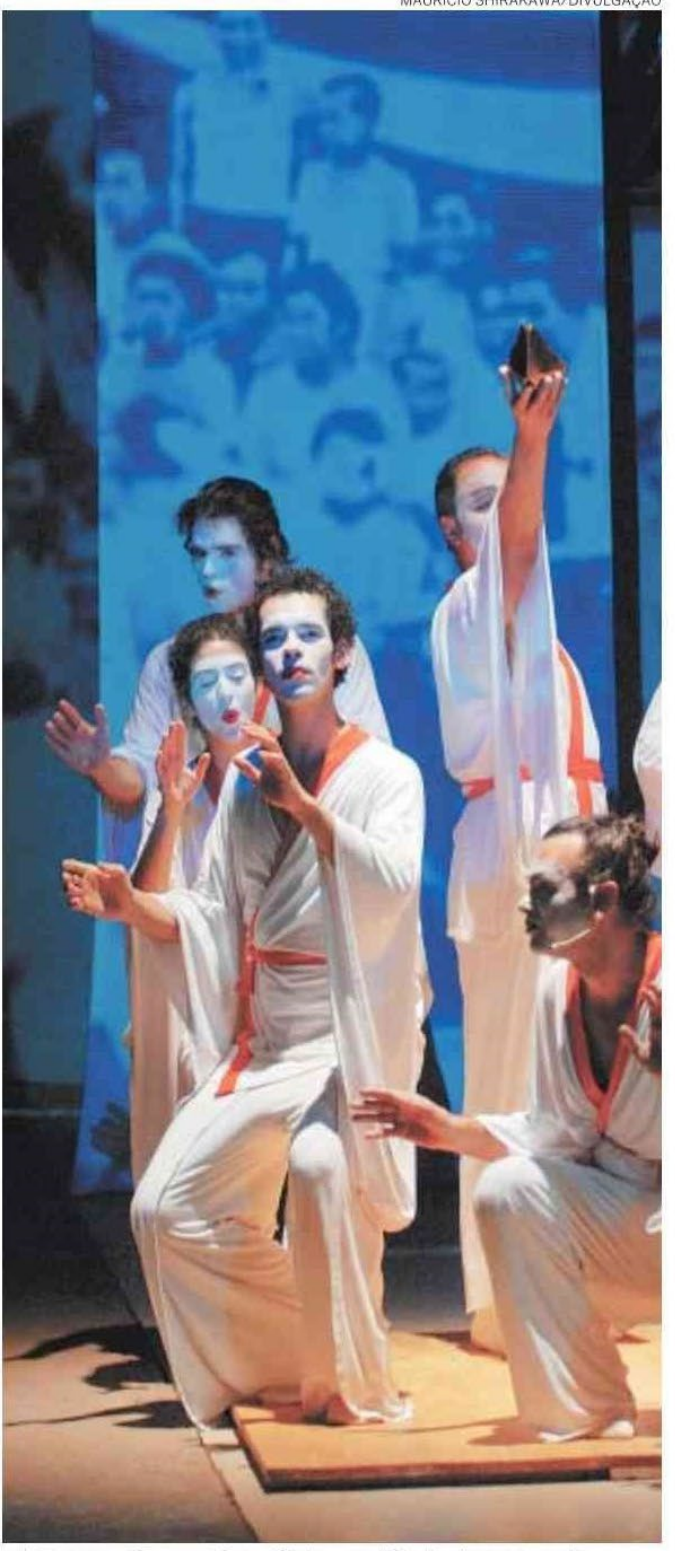

DELCADEZA-Geometria sutil de uma fábula do teatro nô $\begin{array}{ll}\text { delicada de uma fábula do tea- } & \text { de ser apenas um exílio força- } \\ \text { tronô. Talvez tenha faltado, no } & \text { do (embora esse componente }\end{array}$ repertório destes 50 anos, a não seja omitido da narrativa) prospecção da cultura trans- a viagem dos monges é tamormada pela chegada dos imi- bémuma peregrinação aventu-

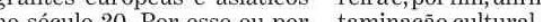
outro motivo, Taniko, narrativa inspirada no repertório de textos clássicos japoneses é, entre conceitos antitéticos bendo -, uma celebração cênicado modo como oteatro oriental representa oelementotrágico. "Transzênico" é mesmo uma boa definicão

APESAR DA VOCAC̄̃O

PARA O COMBATE,

GRUPO ENCENA OBRA QUASE PACÍFICA

Bertolt Brecht, entidade protetora do grupo, recorreu a plificar a potência transformadora do pensamento crítico aplicado ao direito consuetudinário. Com procedimento semelhante, também extraindo da fábula uma moralidade, esconciliaçãa entre pedagogia e gratificação sensorial que oteatro político do século 20 , em grande parte motivado pela teoria brechtiana, relegou ao
planodas preocupacōessecunplano das preocupaçōes secunaliança repousa sobre uma fundação conceitual diferente. $\mathrm{Na}$ perspectiva do Teatro Oficina, o motor de transformação possivel e agora o vinculo amoro-
so. A lei emanada do costume podee deve ser revogada quando $o$ acordo feito no passado impede a felicidade presente. Com esse mote, o espetáculo sublima a necessidade e a
transforma na metáfora do desejo. Eé assim que se process es em um longo percurso los mares do planeta até chegar ao Porto de Santos. Em v
Sem dúvida, a divindade despedacada e renascida é mito fundador da cultura ocidental e a memoria das celebraçoes alegres, que ocorrem deoportunidade para que o espetáculo misture à limpidez da linguagem oriental aos ritmos musicais eas formas coreográficas do nosso mexidinho habituralista contudo, a cniculção articula conexồes a um tempo lógicas e estéticas entre as convenções espaciais e temporais do teatro nô e as prátipróprio edifontemporanea. proplugar detravessia tornofiguração ampliada da ponte da cena japonesa. Outras coisas do espetáculo seráo, provavelmente, referências a pesquios mo da uma das suas producões. Mas, para quem só tem a experiência livresca da cena oriental, não há estranhamento. Entos cênicos, a nitidez elemenprimárias, o dualismo compleentar das figuras corais são artifícios espetaculareshálongo tempo incorporados à linguagecialo toxto que de bém comovente not e tamlugar de origem desses empréstimos que, incessantemente temos feito sem a intenção de é nossa e essa satife Ohtake trirsa essa satisfeca materlúdio, o devaneio de um erreiro cinquuentão. $\bullet$

Taniko - O Rito do Mar. $90 \mathrm{~min}$ 16 anos. Teatro Oficina (350 lug.) 3106-5300. 6. ${ }^{2}, 21$ h; sáb. e dom., 18 h. R\$20. Até 22/6 


\section{Macumba Antropófaga (2011)}

Teatro. Em Cartaz

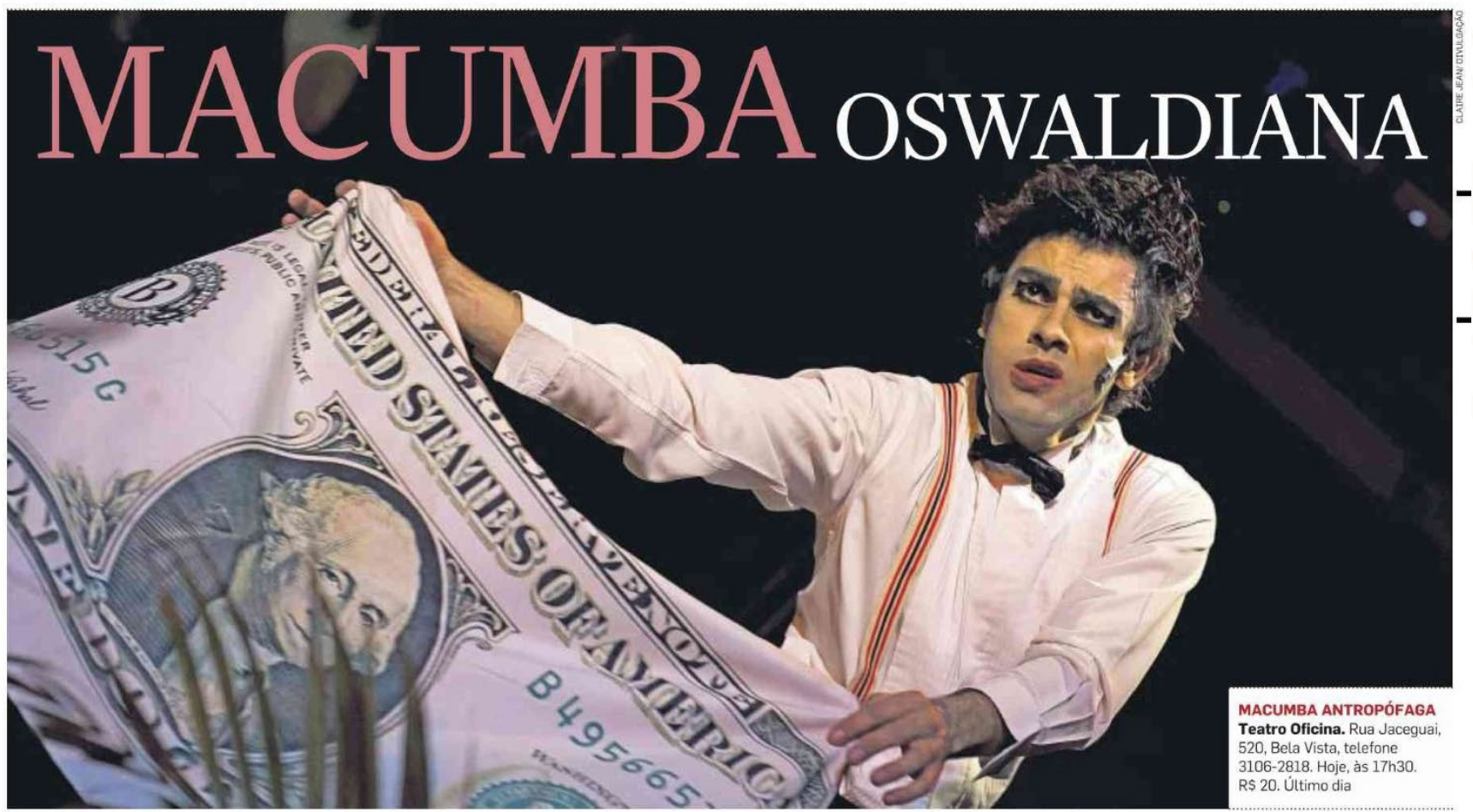

* Crítica:

Mariangela Alves de Lima

e a alegria é a prova dos
nove,Macumba Antropónove, Macumba Antropó-
faga, espetáculo que encerra a temporada no Teatro Oficina, passaria pela prova com distinçăo e louvor. A moçadaque sejuntaaocorodeintér-
pretes no desfile do espetáculo pelas ruas do Bexiga decorou a pelas ruas do Bexiga decorou a
melodiaealetra dascançoses que - acompanhamomovimentoperipatético e, mais do que isso, aprendeu o complexo arranjo que harmonizaas vozes do coral. Parte do público, e não a menor, estárevisitandooespetáculo pe- lo prazer de participar e essa transformação da experiência - singular em cerimônia ritual é um dos desejos explícitos de - uma encenação que considera o teatro um lugar sagrado "que - não pode ser vendido nem comprado". Há uma simpatia fácil, provavelmente de relação consolidada, entre o cortejo formado por atorese públicoeoshabitantes de um bairro que sustenta a maior escola de samba da cidade. Esse elo forjado pela convivência e pela analogia entre dois espetáculo como um humor às vezes empático e às vezes conescendente e irônico. No episodio representado rastro fulgurante na memória Oswald de Andrade, por exem plo, entra em cena uma cabrinh ncarregada de ligar o poeta ao simbolismo da deglutição. E a uma moradora doprédioque enriquece a trama convidando para a cena um gracioso e desinibido papagaio. Algumas crianças vibiracrobacinse, acomodados nasmesas dos ba- ___ es, estâo tambem os critico mprovisados coaquilo. Enfim, nadade novoparacidades habituadas ao teatro de rua mas, para os paulistanos, um for- forçodemobilizač̃oenormeesmato teatral cada vez mais im- tro Oficina procura a amplitude possivel em uma metropole geográficaadequadaaessadimencujos espaços de convivência sãolmaginána eorompimentonminguam diariamente. Este e sico "edificio em direção à rua"c, um dos sentidos que o Teatro por si só, um transbordamento Oficina Usyna Uzona recria de que faz da cidade o teatro. modo vigoroso nesse trajeto ini- Os episódios seguintes refecial do espetáculo baseado no rem-se as circunstâncias estétiManifesto Antropófago. O teatro co-históricas do modernismo para multidões deve invadir brasileiro è̀s figuras importan-
A cena invade as ruas na evocação da antropofagia feita pelos atores do Oficina

tes para a arte e para a vida afetivade Oswaldde Andrade. Biografí efragmentos de outros escririvtura com o passopisto classe social de origem de Os. wald de Andrade e de sua companheira Tarsila do Amaral. "Eu me jogo seminua de minha posiçãosocial abaixo", exclamaaanima do Poeta na peça $A$ Morta. Na transposiçãoespetacular, ofascinio pela estética da burguesia é recriado para que a "queda" $\mathrm{n}$ ejaigualmenteimpressionante. Oluxo sugerido pelatendaalmofadada, a bebida servida sobre a bigorna dourada, o som de jazz o choque e imersão no "país da Cobra Grande". Em surdina princípio,oritmodocoroindígenavaiexpulsandodacenaacultu- o público caminha para a parte daencenaçãodiretamente inspirada no Manifesto Antropófago. Embora o publico continue alegríssimo, são de outra ordem osprazeres proporcionados pela dramatizaçáo dos parágrafos do Manifesto. Sempre escrupuloso emrelaçãoàs fontes textuais que adota para seus espetáculos, José Celso não exclui sequer uma das combativas afirmaçoes do vas dessaverdadeirasímulaculvasdessaverdadeira súmulacultur sá expostas com clareza ç̃o com a fonte principal do petáculo não ficam muito nítidas. Personagens, falas e situações de outras peças de Oswald de Andrade, por exemplo, deixam a impressão insatisfatória de que falta o resto da cena. Em particular a iconografia católica perdeuaimportância na civilizadedoséculo 20 .Verónicas e Cirineus talvez necessitem contextos explicativos para ter algum efeito cômico. Invocar o Papa, o ça,eumjuizda "VaradeFamília" para simbolizar as instâncias autoritáriasherdadas eaindavigentesé um procedimento ilustrotvo emperfeitomerto ses antropófagas. No entanto, o cstilo predominante no espetápo da celebraçáo oficiad por um coro e o tratamento farẽco dado a essas personagens ấ Por cautro lado, outras associan Por outrolado, outras associacoes entre os axiomas do manfestoe fatos analogos na artee na hich igorosae,por essarazão,estimuonher no tempo presente mesmos fatos sob roupagens lieimmenticoup ões "antropófagas" nos campo in em um tecido ao mesmo tempo corentec muitobonito, querseasoba formadorapedomangue beat quer se manifestada através das figuras dos intelectuais franceses que compreenderam e se namoraram das civilizações indigenase dos africanos desterrados no nosso território. Em ouras épocas, reverenciando o gênio tutelar da Antropofagia, os artistas do Oficina reafirmavan o caráter "forte e vingativo" da nossa mescla cultural. Hoje, a que parece, exibem uma relativa serenicade para tentar "acreditar nos sinais, acreditar nos in 
